\title{
Production of flour as a tool for valuation of the fish residues
}

\author{
Weslei Martins dos Santos, Beatriz Simões Valente, Willian Cezar Nadaletti, Maurizio Silveira \\ Quadro, Simone Pieniz, Robson Andreazza e Carolina Faccio Demarco
}

Universidade Federal de Pelotas, RS, Brasil

weslei93@hotmail.com; bsvalente@terra.com.br; williancezarnadaletti@gmail.com; mausq@hotmail.com; nutrisimone@yahoo.com.br; robsonandreazza@yahoo.com.br; carol_demarco@hotmail.com

\begin{abstract}
The aim of this study was to evaluate the flour production for the evaluation of fish residues. This study was carried out in two experiments. The first was characterized by the production of flour from the filleting of Abrótea fish, while in the second was used the shrimp residue. The treatments in both experiments consisted of two methods of dehydration: oven (T1) and microwave (T2), with four replicates per treatment. The moisture contents, ashes, total nitrogen and crude protein were evaluated. The results showed that flour production is an important tool for the evaluation of fish waste. The flour of Abrotea and shrimp are an important source of protein and minerals that can be used for animal feeding. The microwave method can be used in the preparation of fish and shrimp flours because it does not alter the crude protein content. The microwave is more advantageous than the oven method because it speeds up the dehydration process of fish waste. The flour produced is an alternative for artisanal fishermen and can bring income to fishermen, fishers'families and also to poor communities.
\end{abstract}

Keywords: Environmental contamination, Environmental management, Fish, Solid waste

\section{Resumo}

O objetivo deste estudo foi avaliar a produção de farinha para valoração dos resíduos de pescados. Os estudos consistiram de dois experimentos. O primeiro se caracterizou pela fabricação da farinha dos resíduos da filetagem de abrótea enquanto que no segundo foram utilizados os resíduos de camarão-rosa. Os tratamentos em ambos os experimentos foram constituídos por dois métodos de desidratação: estufa (T1) e micro-ondas (T2), com quatro repetições por tratamento. Foram avaliados os teores de umidade, cinzas, nitrogênio total e proteína bruta. Os resultados demonstraram que a produção de farinha é uma importante ferramenta de valoração dos resíduos de pescado. A farinha de abrótea e de camarão é uma importante fonte de proteína e de minerais podendo ser utilizadas na aqüicultura. O método em forno de micro-ondas pode ser utilizado na preparação das farinhas de abrótea e de camarão por não alterar o teor de proteína bruta. O forno de micro-ondas é mais vantajoso do que a estufa porque acelera o processo de desidratação dos resíduos de pescado. A farinha produzida é uma alternativa para os pescadores artesanais e pode trazer renda para os pescadores, familia dos pescadores e também para as comunidades carentes.

Palavras-chave: Contaminação ambiental, Gestão ambiental, Pescados, Resíduos sólidos 


\section{Introduction}

Fishing activity in the Brazil is essential in food security by providing an important source of protein and subsistence for millions of families. Brazil produces approximately 1 million and 240 thousand tons of fish per year, having about $45 \%$ of this production coming from artisanal fishing (BRASIL, 2015).

The southern region of the Rio Grande do Sul state contributes significantly for fishing, guaranteeing the supply of different fish species (VALENTE et al., 2016). The productive chain is based on extractive catch which is carried out by artisanal fishermen, and on the processing stage, which consists of the cleaning and filleting the fish, being carried out mainly in beneficiation units located in their own communities.

Furthere, there is a large volume of residues being generated daily, which varies according to the species and processing method used (FELTES et al., 2010). In the filleting process, the amount of residues achieves $65 \%$ of the weight, meaning that approximately 500 to $700 \mathrm{~g}$ of the fish is discarded (VALENTE et al., 2016). These discards are mainly viscera, caudal fin, spinal cord, fin, scales and meat remains. Otherwise, when the fish is only gutted, the production generates around 8 to $16 \%$ of solid waste. Regarding to shrimp processing, the approximate volume is $40 \%$ of the weight of the crustacean, which compromises the cephalothorax and the exoskeleton (FERNANDES et al., 2013).

Inappropriate waste disposal practices in water resources contribute to environmental contamination. The significant increase in the phosphorus and nitrogen levels and the decrease in dissolved oxygen concentration, which is essential for the maintenance of aquatic life are situations that can be noticed in the environment through the process of eutrophication and fish mortality.

An alternative to reduce these situations of environmental vulnerability is the use of fish waste for the production of flour. Lima et al. (2007) points out that the prohibition on use of animal protein derived from mammals and birds, has turned fishmeal and crustaceans an important source of animal protein.

Thus, many studies have been carried out in order to know the product. Eyng et al. (2010) studied the inclusion of flour produced from tilapia filleting in broiler feeds. The authors found that the supply of tilapia flour at levels up to $8 \%$ in the diet did not affect the performance of the animals, providing a reduction in phosphorus and blood calcium values. Rossato et al. (2014) found that the use of flour from catfish waste at 30\% of incorporation in the diet provided higher feed efficiency in young catfish. Godoy et al. (2016) found that the meat and bone from pintado flour showed better digestion for crude protein, calcium and phosphorus while meat and bone meal of tilapia showed higher value for ethereal extract and digestible energy. The authors also found that the meat and bone flour from catfish presented the highest mineral content. However, knowing its chemical composition is an essential factor to standardize flour quality, along with methods to obtain a more stable product with better nutritional characteristics (PIRES et al., 2014). Based on it, the aim of this study was to evaluate the flour production as a tool for valuing fish waste.

\section{Materials and methods}

The work was carried out at the Laboratory of Environmental Chemistry at the Engineering Center (CEng) of the Federal University of Pelotas (UFPEL), located in the city of Pelotas/RS.

Studies were performed in two experiments. The first one was based on the production of the flour from Abrótea filleting (head and carcass) (Urophycis brasilienis) while in the second one was used the pink-shrimp residue (abdomen, cephalothorax and tail) (Farfantepenaeus subtilis). The feedstock were obtained from the Fishermen's Colony Z-3, located $20 \mathrm{~km}$ from the city of Pelotas. The material was frozen at $-5^{\circ} \mathrm{C}$ of temperature and thawed at room temperature for further flour production.

The production of flour from the Abrótea filleting and from shrimp cleaning was carried out using two dehydration methods, which consisted of T1 (dehydration in oven) and T2 (dehydration in microwave oven) for both experiments, with four replicates per treatment. During the application of the heat treatments, fish waste was mixed every 5 minutes in order to obtain equal dehydration.

T1 samples were dehydrated in an oven with nominal power of $600 \mathrm{~W}$ and forced air circulation at fixed temperature of $70^{\circ} \mathrm{C}$ for 24 hours. The treatment in microwave Panasonic ${ }^{\circledR}$ oven, nominal power of $900 \mathrm{~W}$ and operating frequency of $2.450 \mathrm{MHz}$, was performed for 15 minutes. The samples were crushed with Marconi ${ }^{\circledR}$ mill, model MA 048 and packed in polypropylene packaging with capacity of $500 \mathrm{~g}$.

Chemical composition analyses were performed in triplicate at the Laboratory of Animal Nutrition in the Department of Zootechny (DZ) of the School of Agronomy Eliseu Maciel (FAEM) of UFPEL. The evaluations were carried out according to the methodology of Silva and Queiroz (2004). The moisture content was calculated through the equation UMID $=100 \%$ - \%MS, while the ash (CZ), by the total combustion of the sample in a muffle furnace at $600^{\circ} \mathrm{C}$. Total nitrogen $(\mathrm{N})$ was determined by the digestion of the sample in sulfuric acid and subsequent distillation in Kjedahl apparatus. Crude protein (CP) content was calculated by applying factor 6.25 .

Statistical analysis design used was completely randomized. Data referring to selected variables were submitted to analysis 
of variance (ANOVA), using the program "Statistical Analysis System” version 9.1 (SAS Institute Inc. 2002-2003) with the means analysed by the Tukey test at $5 \%$.

\section{Results and discussion}

Table 1 presents the chemical composition of Abrótea filleting waste flour (Urophycis brasilienis) obtained through two methods of dehydration. There were no significant differences between the treatments at the oven (T1) and at the microwave oven (T2) for moisture, ash, total nitrogen and crude protein. The results suggest that the species, the environment, the time of year, the stage of sexual maturation, the quality, the age and the part of the analysed body possibly have more influence on the chemical composition of the flour than the heat treatment used in the production.

Table 1 - Chemical composition of flour from abrótea filleting waste dehydrated in oven and microwave oven

\begin{tabular}{|c|c|c|c|c|}
\hline \multirow[t]{2}{*}{ Treatments } & \multicolumn{4}{|c|}{ Chemical composition } \\
\hline & HUMID & $\mathrm{CZ}$ & $\mathrm{N}$ & $\mathrm{CP}$ \\
\hline & \multicolumn{4}{|c|}{--------------------- \% ----------------------- } \\
\hline T1 - Oven & $80.3 \pm 0.09^{a^{*}}$ & $18.8 \pm 0.06^{\mathrm{a}}$ & $10.5 \pm 0.08^{\mathrm{a}}$ & $54.3 \pm 0.08^{\mathrm{a}}$ \\
\hline T2 - Microwave oven & $78.4 \pm 0.04^{\mathrm{a}}$ & $20.7 \pm 0.08^{\mathrm{a}}$ & $11.5 \pm 0.03^{\mathrm{a}}$ & $52.6 \pm 0.03^{\mathrm{a}}$ \\
\hline
\end{tabular}

${ }^{*}$ Means followed by the same letter, within the same column, do not differ among themselves by the Tukey test at $5 \%$. HUMID: humidity; CZ: ashes; $\mathrm{N}$ : total nitrogen and $\mathrm{CP}$ : crude protein

However, it can be verified that the fish presents a high nutritional value independent of mentioned factors and the method used for its dehydration. The high content of crude protein, total nitrogen and ash are present constantly in fish carcasses. This fact is demonstrated in the research conducted by Petenuci et al. (2010) that analysed the chemical composition of tilapia spine flour (Oreochromis niloticus) dehydrated in commercial oven at $180^{\circ} \mathrm{C}$ for 4 hours and verified $14.2 \%$ of humidity, $18.3 \%$ of ashes, $6.5 \%$ of nitrogen and $40.8 \%$ of crude protein. Lima et al. (2012) characterized chemically dehydrated steaks of caranha (Piaractus mesopotamicus) at $105^{\circ} \mathrm{C}$ until constant weight and obtained $76.9 \%$ of humidity, $0.92 \%$ of ash, $2.7 \%$ of nitrogen and $17 \%$ of crude protein. Costa et al. (2014) analysed the chemical composition of two species of jaraqui (Semaprochilodus spp.) dehydrated in an oven at $110^{\circ} \mathrm{C}$ with forced ventilation until constant weight. The authors observed that the moisture contents $(72.8 \%)$ and ashes $(4.1 \%)$ in the species of jaraqui with fine scale $(S$. taeniurus) were significantly lower than the species with coarse scales (S. insignis), presenting respectively $76.4 \%$ and $4.7 \%$. However, the crude protein content did not differ between the two species, presenting values around $13.6 \%$.

It can be observed in Table 2 that there was no statistical difference among moisture contents, ashes, total nitrogen and crude protein of the pink-shrimp flour (Farfantepenaeus subtilis), obtained by dehydration in oven (T1) and microwave oven (T2) treatments. Which again, it shows the influence of the species, the type of food consumed, the age and the regions of the crustacean body used to make the flour. The results disagree with Castro and Pagani (2004) who evaluated the chemical composition of shrimp head flour (Litopenaeus vannamei) at temperatures of 50,60 and $70^{\circ} \mathrm{C}$ in an oven with air circulation for 30 minutes and verified a variation of the protein content and ash as a function of the drying temperature. Pastorini et al. (2002) explain that drying with air circulation is a method that can cause some changes in the biochemical structure of the samples.

Table 2 - Chemical composition of flour from shrimp waste dehydrated in oven and microwave oven

\begin{tabular}{c|c|c|c|c}
\hline \multirow{2}{*}{ Treatments } & \multicolumn{3}{c}{ Chemical composition } \\
\cline { 2 - 5 } & HUMID & CZ & N & \multicolumn{2}{|c}{ CP } \\
\hline T1 - Oven & & $18.0 \pm 0.06^{\mathrm{a}}$ & $5.9 \pm 0.09^{\mathrm{a}}$ & $55.0 \pm 0.09^{\mathrm{a}}$ \\
\hline T2 - Microwave oven & $75.9 \pm 0.30^{\mathrm{a}^{*}}$ & $17,5 \pm 0.08^{\mathrm{a}}$ & $8.7 \pm 0.04^{\mathrm{a}}$ & $56.4 \pm 0.04^{\mathrm{a}}$ \\
\hline
\end{tabular}

${ }^{*}$ Means followed by the same letter, within the same column, do not differ among themselves by the Tukey test at 5\%. HUMID: humidity; CZ: ashes; N: total nitrogen and CP: crude protein

Another aspect to be considered is the variation in chemical composition of flours produced from identical species and dehydration methods. Portella et al. (2013) evaluated the chemical composition of cephalothorax and abdomen flour of amazonian shrimp (Macrobrachium amazonicum) in a forced air circulation oven, at a fixed temperature of $70^{\circ} \mathrm{C}$ for 24 hours, and obtained $76.5 \%$ of moisture, $1.3 \%$ of ash, $3.4 \%$ of nitrogen and $21.5 \%$ of crude protein. However, Furuya et al. (2006), analy- 
sing the chemical composition of the cephalothorax and abdomen flour of the same shrimp species, in a forced air circulation oven, at the same temperature and time of dehydration, values found were $70.3 \%$ for moisture content, $1.5 \%$ of ash, $3.9 \%$ of nitrogen and $24.8 \%$ of crude protein. Lacerda et al. (2009) emphasize that the oven can cause a volatilization of organic acids and ammonium causing biochemical changes in the composition of the material.

Regarding with the dehydration method employed, the microwave oven provided a reduction in the drying time of the Abrótea and shrimp filleting residues when compared to the technique in oven with forced air circulation. Valente et al. (2015) also found that the replacement of the oven with forced air circulation by the microwave oven in the preparation of the Eisenia fetida earthworm flour accelerates the dehydration process. Corroborating with the results Li et al. (2016) argue that the use of the microwave oven reduces the preparation time of food and decreases the energy demand and costs of the producing process.

Pastorini et al. (2002) observed that in the microwave oven, the plant material of Phaseolus vulgaris L. and Zea mays L. were dried between 3 and 4 minutes, while in the oven, the values remained constant after 48 hours. Likewise, Souza et al. (2002) point out that for forage and silage samples, the drying time in an oven at $105^{\circ} \mathrm{C}$ is approximately 12 hours and the temperature of $65^{\circ} \mathrm{C}$, around 72 hours, which drying can be performed with microwave radiation in 14 minutes.

\section{Conclusion}

Flour production is an important tool for valuing fish waste and is an alternative for poor communities of Fishermen Colonies, which is needing to improve their income. Abrótea and shrimp flour are an important source of protein and minerals that can be used in animal feed.

The microwave oven method can be used to prepare abrótea and shrimp flour because it does not alter the crude protein content. In addition, the results showed that the microwave oven is more advantageous than the regular oven because it speeds up the dehydration process of fish waste.

\section{Acknowledgments}

To FAPERGS and CNPq for financial support of this project.

\section{References}

BRASIL. MINISTÉRIO DA PESCA E AQUICULTURA. Disponível em: http://www.mpa.gov.br/. Acessado em: 29 de jul. 2015.

CASTRO AA, PAGANI GD. Secagem e composição química da cabeça de camarão (Litopenaeus vannamei Boone) a diferentes temperaturas. Rev. Bras. Produtos Agroindust. 2004;6(2): 123-129.

COSTA TVDA, MACHADO NDEJB, BRASIL RJM, FRAGATA NP. Caracterização físico-química e rendimento do filé e resíduos de diferentes espécies de jaraqui (Semaprochilodus spp.). Bol. Inst. Pesca. 2014;40(1): 35-47.

EYNG C, NUNES RV, POZZA PC, SILVA WTMDA, NAVARINI FC, HENZ JR. Farinha de resíduos da indústria de filetagem de tilapias em rações para frangos de corte. R. Bras. Zootec. 2010;39(12):2670-2675.

FELTES MMC, CORREIA JFG, BEIRÃO LH, BLOCK JM, NINOW JL, SPILLER VR. Alternativas para a agregação de valor aos resíduos da industrialização de peixe. Rev. Bras. Eng. Agríc. Amb. 2010;14( 6): 669-677.

FERNANDES TM, SILVA JADA, SILVA AHADA, CAVALHEIRO JMDAO, CONCEIÇÃO MJDA. Flour production from shrimp by-products and sensory evaluation of flour-based products. Pesq. Agropec. Bras. 2013;48(8): 962-967.

FURUYA, WM et al. Composição centesimal e perfil de ácidos graxos de camarão d'água doce. Rev. Bras. Zootec. 2006;35(4): 1577-1580.

GODOY AC, FRIES E, CORRÊIA AF, MELO IWA, RODRIGUES RB, BOSCOLO WR. Apparent digestibility of fish meat and boné meal in Nile tilapia. Arch. Zootec. 2016;65(252): 341-348. 
LACERDA, MJR, FREITAS KR, SILVA JWDA. Determinação da matéria seca de forrageiras pelos métodos de microondas e convencional. Biosci. J. 2009;25(3): 185-190.

LI H, QU Y, YANG Y, CHANG S, XU J. Microwave irradiation - A green and efficient way to preteat biomass. Bioresource Technol. 2016;199: 34-41.

LIMA SBPDE, RABELLO CBV, DUTRA JUNIOR WM, LUDKE MDOCMM, COSTA FGP. Valor nutricional da farinha da cabeça do camarão marinho Litopenaeus vannamei para frangos de corte. Rev. Caatinga. 2007;20(3): $38-41$.

LIMA MDE, MUJICA PIC, LIMA AM. Caracterização química e avaliação do rendimento em files de caranha (Piaractus mesopotamicus). Braz. J. Food Technol. 2012; 4: 41-46.

PASTORINI LH, BACARIN MA, ABREU CM. Secagem de material vegetal em forno de microondas para determinação de matéria seca e análises químicas. Ciênc. Agrotec. 2002;26(6): 1252-1258.

PETENUCI ME, STEVANATO FB, MORAIS DRDE, SANTOS LP, SOUZA NEDE, VISENTAINER JV. Composição e estabilidade lipídica da farinha de espinhaço de tilápia. Ciênc.Agrotec. 2010;34(5): 1279-1284.

PIRES DR, MORAIS ACNDE, COSTA JFDA, GÓES, LCDSDEA, OLIVEIRA GMDE. Aproveitamento do resíduo comestível do pescado: aplicação e viabilidade. Revista Verde de Agroecologia e Desenvolvimento Sustentável. 2014;9(5): 34-46.

PORTELLA CDEG, SANT'ANA LS, VALENTI WC. Chemical composition and fatty acid contents in farmed freshwater praws. Pesq. Agropec. Bras. 2013;48(8): 1115-1118.

ROSSATO S, LAZZARI R, LIBERALESSO DE FREITAS I, MASCHIO D, CORREIA V, RADÜNZ NETO J. Diferentes níveis de incorporação de farinha de resíduos de jundiás (Rhamdia quelen) cultivados na dieta. Arq. Bras. Méd. Vet. Zootec. 2014;66(3): 894-902.

SAS Institute. Statistical analysis system. Release 9.1. (Software). Cary, 2003.

SILVA DJ, QUEIROZ ACDE. Análise de Alimentos: Métodos Químicos e Biológicos. Viçosa: Universidade Federal de Viçosa, 2004.

SOUZA GB, NOGUEIRA ARA, RASSINI JB. Determinação de matéria seca e umidade em solos e plantas com forno de microondas doméstico. São Carlos: Embrapa Pecuária Sudeste. 2002.9p.

VALENTE BS, XAVIER EG, MORSELLI TGA, LOPES M. Proteína bruta da farinha de minhoca da espécie Eisenia fetida (Savigny, 1826) submetida a diferentes tratamentos térmicos. Rev. Bras. Higien Sanid Anim. 2015;9(1): 102-107.

VALENTE BS, XAVIER EG, PEREIRA HS, PILOTTO MVT. Compostagem de resíduos da filetagem de pescado marinho e casca de arroz. Rev. Bras. Saúde Prod. Anim. 2016;17(2): 237-248. 